\title{
A Study on Entrepreneurship Education and Entrepreneurial Attitude in Malaysia - The Relationship between Employment and Unemployment Analysis
}

\author{
J Jose Prabhu \\ Research Associate, International Centre for Entrepreneurship Learning \& Research, \\ Tiruchirappalli, Tamil Nadu, India
}

\begin{abstract}
How to cite this paper: J Jose Prabhu "A Study on Entrepreneurship Education and Entrepreneurial Attitude in Malaysia - The Relationship between Employment and Unemployment Analysis" Published in International Journal of Trend in Scientific Research and Development (ijtsrd), ISSN: 24566470, Volume-3 | Issue-3, April 2019, pp.840-842, URL: https://www.ijtsrd.c om/papers/ijtsrd23 028.pdf

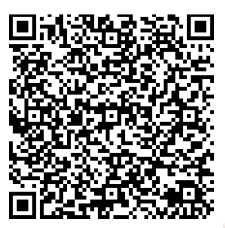

IITSRD23028
\end{abstract}

Copyright (C) 2019 by author(s) and International Journal of Trend in Scientific Research and Development Journal. This is an Open Access article distributed under the terms of the Creative Commons

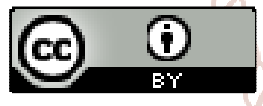
Attribution License (CC BY 4.0) (http://creativecommons.org/licenses/ by $/ 4.0$ )

\section{Introduction}

Unemployment is a vital issue in creating economies. High joblessness implies that work assets are not being utilized proficiently. Subsequently, full work ought to be a noteworthy macroeconomic objective of any legislature since it augments yield.

In macroeconomic structure, Hanapi, Z., \& Nordin, M. S. (2014) explained about entrepreneurship education is an outstanding relationship, which expresses that there is a negative connection between joblessness rate and genuine GDP. For a time of more than thirty years, a few financial analysts found solid exact normality in this pervasive relationship. It has pulled in the consideration of many, in light of the powerful observational consistency as well as more significantly its job as a macroeconomic structure square. The exact appraisals of entrepreneurship education and training, which is a proportion of the responsiveness of unemployment to yield development, are essential as they demonstrate the expense of joblessness as far as yield.

The goal of this paper is to look at whether a business training connection among yield and joblessness is available in the Malaysian economy. We are quick to locate the dimension of GDP development rate expected to accomplish full work. Henceforth, from this investigation we will almost certainly decide the causal connection among yield and joblessness.

\section{Unemployment Rate in Malaysia:}

Noor, Z. M., Nor, N. M., \& Ghani, J. (2007) found that Malaysia's unemployment is moderately low and stable at around three percent which implies the population is experiencing near full work. The nation achieved its most minimal dimension of joblessness in 2018, with a rate of 3.3 percent.(figure 1) Malaysia's dynamic economy is viewed as one of the most grounded in South East Asia. Together with long periods of political strength, it has been supporting such a low joblessness rate and great development rates every year.

Notwithstanding, regardless of these constructive measurements, news reports express that the quantity of employment searchers and those jobless - the three percent - are commonly youngsters, the two alumni and non- 
graduates, who experience experienced issues entering the activity advertise. Along these lines, the Malaysian government is urging organizations to open up work openings explicitly to youthful grown-ups. The ideal monetary atmosphere should help. However, there have additionally been a few objections about underemployment and gender orientation separation inside the nation.

Industry has been a solid supporter of GDP and as of now gives around 30 percent of business openings. Be that as it may, considerably more - around 50 percent - of GDP is produced by the administrations area. Given the nation's solid and developing economy, normal GDP per capita is developing at expanding rates too.

As indicated by the report, the unemployment rate in February 2018 dropped 0.1 rate point to $3.3 \%$. In the interim, the year-on-year correlation saw the nation's joblessness rate to be 0.2 rate focuses lower than February 2017. On an occasionally balanced month-on-month premise, the unemployment rate (regularly balanced) for February 2018 diminished 0.1 rate point to 3.2 percent.

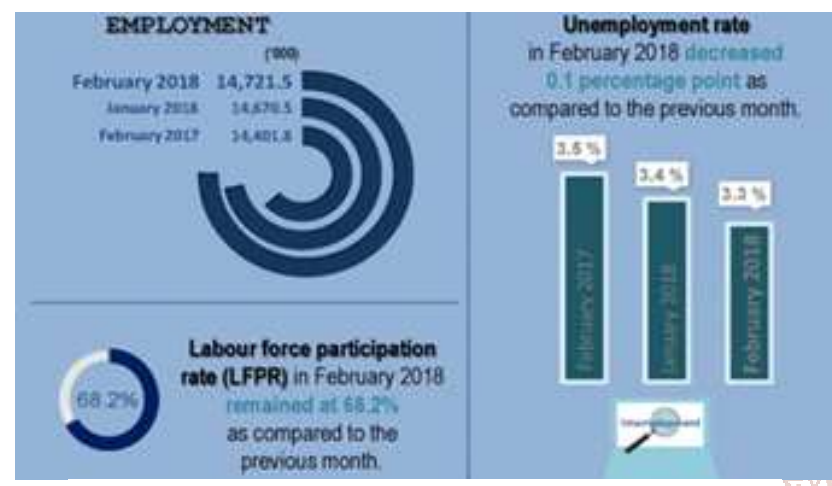

Figure 1 : Malaysia's unemployment rate at $3.3 \%$ in February 2018 - Source : The Department of Statistics Malaysia (DOSM) has just released its latest Key Statistics of Labour Force in Malaysia for February 2018.

Entrepreneurship Attitude among Malaysian Students: Shariff, M. N. M., \& Saud, M. B. (2009) The attitude of individual to get include in the field of entrepreneurship is driven by various variables that can be classified as a Push Factors and Pull Factors. The Push Factors join dissatisfaction that acquired pioneering society. Disappointment results from constrained chances, financial downturn and disappointment. Force Factors consolidate brain research and benefit. People will be pushed into entering business because of the disappointment looked because of constrained openings for work and social portability. Financial downturn likewise makes people be impacted in getting to be business visionaries in view of the absence of openings for work in both general society and private parts.

Another reason is for people who don't have work fulfillment in his/her present employments either in view of the activity itself, inadmissible compensation, clashing with administration or association culture. This is believed to be improper which may prompt innovative dispositions. For certain people who are as of now in the gathering with rich enterprise culture, ceaseless socialization process with the help and help as material and good will legitimately or in a roundabout way urge that person to enter business.
Psychological encouragement additionally makes people to progress toward becoming impacted by entrepreneurship. The individual sense of self to do something that is self-made and being a claim manager may likewise prompt entrepreneurial attitudes. Aside from this, the drive to make a benefit is a solid spark for yearning business visionary. The benefit got from business is seen by numerous individuals to be considerably more than being a simple worker.

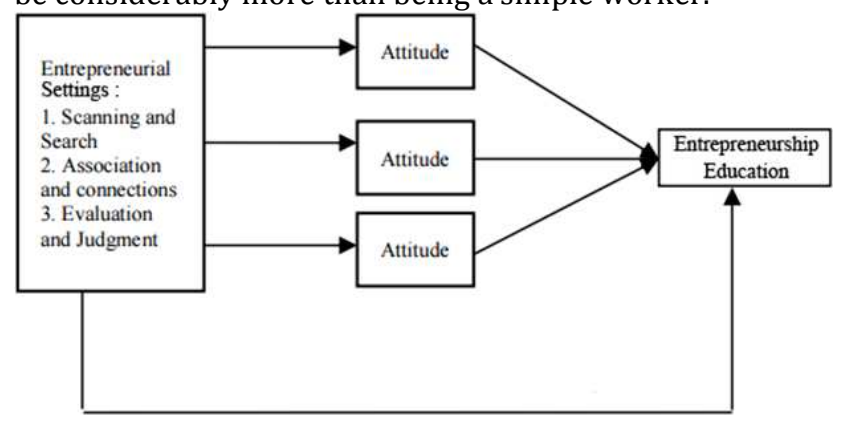

Figure 2: Entrepreneurial Attitude through Entrepreneurship Education

Entrepreneurship Education and Employment:

Entrepreneurship education thinks about in the colleges were researched crosswise over grounds in colleges by many researchers. Peterman, N. E., et al(2003). proposed a direct relapse strategy and found a critical positive relationship between's interest in pioneering projects and adventure manifestations (Smith 2008). Enthusiasm for entrepreneurship and the improvement of business people stayed high both all through scholarly world. The contributing components were; initially, the predominant financial conditions, and besides, the ongoing national government accentuation on independent venture improvement and business that offered ascend to schools and colleges perceiving, that beginning and working a business as feasible vocation options merits scholastic consideration (Kuratko, D. F. 2005).

The discussion in the entrepreneurship institute about whether enterprise could be educated as scrutinized by many researchers. 'Entrepreneur' identified with a matter of identity and psychological characteristics, and the contention was that ability and disposition couldn't be educated (Vesper, K. H., \& Gartner, W. B. (1997). Many researchers contended and proposed that entrepreneurship could be instructed as a subject and was affirmed by Peter Drucker's words, cited by (Kuratko, D. F. 2005).as it is winding up obvious that entrepreneurship or certain features of it very well may be instructed. According to Clark, B. R. 1998 entrepreneurship education exercises were nearer to create than science driven by experience more than orderly educating methodologies.

Robinson, P. B., et al (1994)A general education impacts entrepreneurship as far as getting to be independently employed and achievement. Experience has a comparable relationship despite the fact that not as solid. Future examinations need to look at the effect of explicit sorts of training, for example, business schools or entrepreneurship training centre, on the pioneering results in the investigations.

\section{Conclusion and Recommendations:}

As a conclusion, creating entrepreneurial graduates is in this way fundamental for our future achievement. Colleges and 
other advanced education foundations ought to be preferably put to open students to situations which cultivate entrepreneurial attitudes and the viability of the entrepreneurship programs are critical keys to deliver increasingly youthful business people in future. The program itself can teach our young age to be progressively beneficial in the wake of moving on from their examinations at college level. As opposed to getting to be unemployment, it is great to channel their inventiveness and vitality towards business which is currently turning into a profitable field in this world. As referenced before, different nations are currently completing a great deal of work to build up their childhood in entrepreneurship. As a creating nation, Malaysia ought to do likewise to improve and create in the nation's economy. In the event that this advantage is being utilized in a legitimate manner, they not exclusively can create their own salary yet additionally can assist our nation with boosting up its monetary advancement. The majority of this begins from education.

\section{References:}

[1] Hanapi, Z., \& Nordin, M. S. (2014). Unemployment among Malaysia graduates: Graduates' attributes, lecturers' competency and quality of education. Procedia-Social and Behavioral Sciences, 112, 1056-1063.

[2] Noor, Z. M., Nor, N. M., \& Ghani, J. (2007). The relationship between output and unemployment in Malaysia: Does Okun's law exist. International Journal of Economics and Management, 1(3), 337-344.
[3] Shariff, M. N. M., \& Saud, M. B. (2009). An attitude approach to the prediction of entrepreneurship on students at institution of higher learning in Malaysia. International Journal of Business and Management, 4(4), 129-135.

[4] Peterman, N. E., \& Kennedy, J. (2003). Enterprise education: Influencing students' perceptions of entrepreneurship. Entrepreneurship theory and practice, 28(2), 129-144.

[5] Kuratko, D. F. (2005). The emergence of entrepreneurship education: Development, trends, and challenges. Entrepreneurship theory and practice, 29(5), 577-597.

[6] Vesper, K. H., \& Gartner, W. B. (1997). Measuring progress in entrepreneurship education. Journal of Business venturing, 12(5), 403-421.

[7] Clark, B. R. (1998). Creating Entrepreneurial Universities: Organizational Pathways of Transformation. Issues in Higher Education. Elsevier Science Regional Sales, 665 Avenue of the Americas, New York, NY 10010 (paperback: ISBN-0-080433545; hard cover: ISBN-0-08-0433421, \$27)..

[8] Robinson, P. B., \& Sexton, E. A. (1994). The effect of education and experience on self-employment success. Journal of business Venturing, 9(2), 141-156. 